\title{
Kajian Pendugaan Cadangan Karbon Bawah Permukaan Pada Lahan Bekas Terbakar Di Areal Hutan Lindung Gambut Londerang Kabupaten Tanjab Timur
}

\author{
Saputra*, M. Syarif dan Y. Achnopha \\ Jurusan Agroekoteknologi, Fakultas Perttanian, Universitas Jambi Jalan Raya \\ Jambi - Ma. Bulian 15 Mendalo Indah 36136 (082289205428) \\ Email: ari.ardiansyahs25@gmail.com (*Penulis untuk korespondensi)
}

\begin{abstract}
ABSTRAK
Lahan gambut mencakup 3\% dari daratan bumi dan menyimpan sebagian besar sumber daya karbon dunia yang kurang lebih setara dengan $1 / 3$ dari karbon dalam tanah global. Selama kurun waktu 12 tahun terjadi penurunan kandungan karbon sebesar 438 juta ton di provinsi Jambi yang disebabkan oleh perubahan penggunaan lahan, pembukaan lahan, sisem drainase dan dan kebakaran lahan gambut. Adanya penurunan jumlah cadangan karbon tersebut mengindikasikan karbon yang semula berada pada lahan gambut telah teremisi ke atmosfer sehingga berdampak pada pemanasan global. Hutan Lindung Gambung (HLG) Londerang adalah salah satu ekosistem hutan gambut tropis yang masih tersisa di Sumatera bagian tengah dengan kondisi sangat kritis akibat peristiwa kebakaran hutan, dengan demikian fungsi ekologinya tidak lagi berjalan optimal. Penelitian ini bertujuan untuk memprediksi jumlah cadangan karbon bawah permukaan, mengetahui potensi emisi karbon serta memberikan arahan pengelolaan karbon di areal hutan lindung gambut Londerang, Kabupaten Tanjung Jabung Timur. Pelaksanaan penelitian ini menggunakan Metode Survei. Penentuan titik-titik pengamatan dibuat secara transek yaitu tegak lurus terhadap tanggul sungai dengan grid 500 x 1000 m sehingga diperoleh 38 titik pengamatan pada lokasi penelitian seluas $19.00 \mathrm{Ha}$. Jumlah total cadangan karbon bawah permukaan di areal penelitian seluas $19.00 \mathrm{Ha}$ adalah $6.654 .152,19$ ton atau 3502 ton/Ha. Potensi emisi karbon yang dihasilkan akibat hilangnya gambut setebal $10 \mathrm{~cm}$ karena terbakar pada lahan penelitian seluas $1900 \mathrm{Ha}$ adalah sebesar 12367,1 ton $\mathrm{C}$ atau 6,509 ton/Ha. Upaya-upaya yang perlu dilakukan untuk menekan laju emisi karbon dan mempertahankan fungsi lahan gambut sebagai pengikat karbon dalam jumlah yang besar adalah dengan melakukan restorasi hidrologi dan revegetasi.
\end{abstract}

Kata Kunci : Cadangan karbon, gambut, kebakaran

\section{PENDAHULUAN}

Lahan gambut mencakup 3\% (sekitar 4 juta $\mathrm{km}^{2}$ ) dari daratan bumi (Global Peatlands Initiative, 2002) dan menyimpan sebagian besar sumber daya karbon dunia yang kurang lebih setara dengan $1 / 3$ dari karbon dalam tanah global (Hoiijer et al., 2006). Luas lahan 
gambut di Provinsi Jambi yaitu 716.839 ha (termasuk tanah mineral bergambut), merupakan lahan terluas ketiga di pulau Sumatera (Wahyunto et al., 2005).

Hutan Lindung Gambung (HLG) Londerang adalah salah satu ekosistem hutan gambut tropis yang masih tersisa di Sumatera bagian tengah. Luas area HLG ini mencapai 12.500 Ha yang terletak di dua kabupaten yaitu Muaro Jambi dan Tanjung Jabung Timur. Kondisi HLG Londerang saat ini sangat kritis hanya 30\% dari seluruh kawasan yang masih memiliki tegakan pohon. Dengan demikian fungsi ekologinya tidak lagi berjalan optimal. Hilangnya tegakan hutan sebagai akibat dari kebakaran hutan yang setiap tahun terjadi di kawasan tersebut.

Kebakaran mengakibatkan kerusakan pada karakteristik fisik, kimia, dan biologi tanah gambut. Sejalan dengan luasnya lahan gambut yang terbakar, maka degradasi lahan gambut akan semakin meningkat (Saharjo, 2000). Akibat kebakaran terhadap sifat fisik tanah akan mempengaruhi suhu tanah, struktur tanah, serta kemampuan tanah untuk meyerap air. Di samping itu, bulk density akan meningkat yang selanjutnya akan menurunkan porositas tanah (Syaufina 2008). Sedangkan perubahan sifat kimia tanah yang terjadi adalah perubahan bahan bakar menjadi abu yang mengandung berbagai unsur hara seperti N, P, S, dan C akan hilang oleh proses penguapan selama berlangsungnya proses kebakaran.

Kandungan karbon total pada tanah gambut di provinsi Jambi pada tahun 1990 adalah sebesar 1.851 juta ton, sedangkan pada tahun 2002 sekitar 1.413 juta ton. Sehingga selama kurun waktu 12 tahun tersebut telah terjadi penurunan kandungan karbon sebesar 438 juta ton akibat adanya perubahan penggunaan lahan gambut menjadi lahan-lahan pertanian tanaman semusim (padi sawah dan palawija) yang semakin intensif, pembukaan lahan gambut yang mengakibatkan perubahan kondisi lingkungan, sistim drainase yang dilakukan pada lahan gambut selain mengakibatkan pemadatan (compaction) juga mempercepat terjadinya oksidasi atau dekomposisi dari bahan organik, penurunan ketebalan gambut akibat adanya pembakaran atau pengeringan serta pembuatan parit-parit/ kanal menyebabkan hilangnya air di lahan gambut sehingga gambut mudah terbakar dan mengalami subsiden (Wahyunto et al., 2005).

Penelitian ini bertujuan untuk memprediksi jumlah cadangan karbon bawah permukaan, mengetahui potensi emisi karbon serta memberikan arahan pengelolaan karbon di areal hutan lindung gambut Londerang, Kabupaten Tanjung Jabung Timur. 


\section{BAHAN DAN METODE}

Penelitian ini dilaksanakan di areal Hutan Lindung Gambut Londerang, Desa Rawasari, Kecamatan Berbak, Kabupaten Tanjung Jabung Timur, Provinsi Jambi. Lokasi penelitian meliputi wilayah seluas \pm 1.900 ha. Contoh tanah dianalisis di laboratorium Tanah Fakultas Pertanian Universitas Jambi. Penelitian ini dilaksanakan dari bulan Mei sampai dengan bulan Juli 2017.

Pelaksanaan penelitian ini menggunakan Metode Survei. Penentuan titik-titik pengamatan dibuat secara transek yaitu tegak lurus terhadap tanggul sungai dengan jarak titik pengamatan antar transek dibuat dengan jarak 500 m x 1000 m, sehingga dari 1.900 ha areal yang diteliti diperoleh 38 titik pengamatan. Dalam pelaksanaan penelitian dilakukan beberapa tahapan kegiatan yang meliputi tahapan persiapan, survei pendahuluan, survei utama (survei lapang) dan tahap pasca survei lapangan.

Data yang dikumpulkan terdiri dari data utama, data penunjang dan data sekunder. Data utama meliputi bulk density (gravimetri), C-organik (loss on ignition), ketebalan gambut (pemboran), tingkat kematangan gambut (van post) dan tinggi muka air tanah (pengamatan di lapangan). Data penunjang meliputi jenis vegetasi, dan riwayat kebakaran. Data utama diperoleh melalui pengambilan contoh tanah di lapangan dan di analisis di laboratorium. Sedangkan data penunjang diperoleh dari instansi terkait dan pengamatan di lapangan. Data sekunder berupa peta: 1) Peta administrasi, 2) Peta areal HLG, 3) Data curah hujan 10 (sepuluh) tahun terakhir diperoleh dari stasiun penakar curah hujan PT. ATGA.

\section{HASIL DAN PEMBAHASAN}

\section{Sub Grup Tanah}

Berdasarkan hasil pengamatan lapangan dan klasifikasi tanah yang telah dilakukan menurut USDA, tanah di lokasi penelitian terbagi atas enam jenis tanah pada tingkatan sub grup tanah yaitu Typic Haplohemist, Fibric Haplohemist,Typic Haplofibrist, Hemic Haplofibrists, Hemic Haplosaprist dan SapricHaplohemists. Sebaran jenis tanah lokasi penelitian tersaji pada Tabel 1 . 
Tabel 1. Sebaran jenis tanah lokasi penelitian

\begin{tabular}{|c|c|c|c|c|}
\hline No & Subgrup Tanah & Titik Bor & Luas (Ha) & Persentase \\
\hline$\overline{1}$ & Typic Haplohemist & 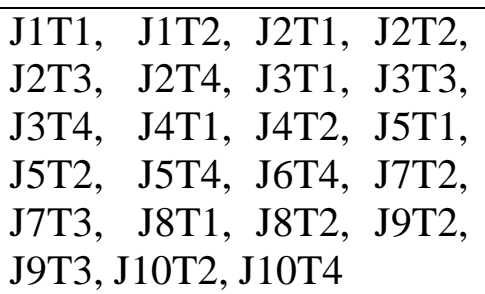 & 1.150 & $60,53 \%$ \\
\hline 2 & Fibric Haplohemist & $\begin{array}{l}\text { J3T2， J5T3，J6T1， J6T3, } \\
\text { J9T1, J10T1 }\end{array}$ & 300 & $15,79 \%$ \\
\hline 3 & Typic Haplofibrist & J4T3, J4T4, J7T1 & 150 & $7,9 \%$ \\
\hline 4 & Hemic Haplosaprist & J7T4, J8T3, J8T4 & 150 & $7,9 \%$ \\
\hline 5 & Sapric Haplohemists & J9T4, J10T3 & 100 & $5,26 \%$ \\
\hline 6 & Hemic Haplofibrists & J6T2 & 50 & $2,62 \%$ \\
\hline \multicolumn{3}{|c|}{ Jumlah } & 1.900 & $100 \%$ \\
\hline
\end{tabular}

Sumber : Hasil pengamatan, Mei 2017

\section{Ketebalan Gambut}

Berdasarkan data yang diperoleh dari pengukuran di lapangan, ketebalan gambut di lokasi penelitian bervariasi dan secara keseluruhan dikategorikan sebagai gambut sangat dalam $(>300 \mathrm{~cm})$, seperti yang tertera pada Tabel 2 .

Tabel 2. Ketebalan gambut lokasi penelitian

\begin{tabular}{ccl}
\hline No & \multicolumn{1}{c}{ Ketebalan gambut $(\mathbf{c m})$} & \multicolumn{1}{c}{ Titik Bor } \\
\hline 1 & $>300-400$ & J9T1, J10T1, J10T2 \\
\hline 2 & $>400-500$ & J1T1, J3T1, J3T2, J4T2, J5T3, J6T2, J6T3, \\
& & J7T1, J7T3, J8T1, J8T2, J8T3, J8T4, J9T2, \\
& J9T4, J10T3, J10T4 \\
\hline 3 & $>500-600$ & J1T2, J2T1, J2T2, J4T1, J4T3, J4T4, J5T1, \\
& J5T4, J7T2, J7T4, J9T3, \\
\hline 4 & $>600$ & J2T3, J2T4, J3T3, J3T4, J5T2, J6T1, J6T4, \\
\hline
\end{tabular}

Sumber : Hasil pemboran, Mei 2017.

Lokasi penelitian memiliki ketebalan gambut berkisar antara $300->600 \mathrm{~cm}$. Ketebalan gambut sangat menentukan besarnya simpanan karbon di lahan gambut, sehingga dapat dijadikan indikator awal besarnya simpanan karbon dalam tanah gambut. Hasil penelitian pada gambut di Kalimantan dan Sumatera menunjukkan hubungan yang erat antara ketebalan gambut dengan karbon tersimpan ditanah gambut (Dariah et al., 2009). Ketebalan gambut merupakan indikator cadangan karbon, Semakin tebal gambut akan semakin tinggi cadangan karbon pada lahan tersebut (Hooijer et al., 2006). 


\section{Tingkat Kematangan Gambut Lapisan Permukaan $(0-60 \mathrm{~cm})$}

Penentuan tingkat kematangan lapisan permukaan gambut pada lokasi penelitian dilakukan dengan metode peras van post. Hasil pengamatan tertera pada Tabel 3.

Tabel 3. Tingkat kematangan lapisan permukaan lokasi penelitian

\begin{tabular}{lll}
\hline No & $\begin{array}{c}\text { Tingkat } \\
\text { kematangan }\end{array}$ & \multicolumn{1}{c}{ Titik Bor } \\
\hline 1 & Fibrik & J2T1, J2T2, J3T3, J3T4, J4T1, J5T1, J5T4, J6T3, J7T1, \\
& & J9T3 \\
\hline 2 & Hemik & J1T1, J1T2, J2T3, J2T4, J3T1, J3T2, J4T2, J4T3, J4T4, \\
& & J5T2, J5T3, J6T1, J6T4, J7T3, J7T2, J7T4, J8T1, J8T2, \\
& & J8T3, J8T4, J9T2, J9T4, J10T2, J10T4 \\
\hline 3 & Saprik & J6T2, J9T1, J10T1, J10T3 \\
\hline
\end{tabular}

Sumber : Hasil pengamatan, Mei 2017

Berdasarkan Tabel 3, lokasi penelitian mempunyai tingkat kematangan gambut lapisan permukaan yang beragam didominasi oleh tingkat kematangan gambut hemik. Tingkat kematangan gambut mempengaruhi nilai bulk density dan C-organik tanah. Semakin matang gambut menyebabkan semakin rendah nilai C-organik tanah dan naiknya nilai bulk density (BV). Proses dekomposisi mengakibatkan penurunan volume gambut sehingga total volume gambut berkurang dan menyebabkan cadangan karbon berkurang (Agus, 2010). Semakin tinggi tingkat kematangan gambut, maka cadangan karbon persatuan volume gambut menjadi semakin tinggi. Namun demikian secara total bukan berarti semakin lanjut kematangan gambut di suatu lokasi, simpanan karbon di tempat tersebut akan semakin meningkat. Akibat proses dekomposisi, gambut mengalami pengurangan volume atau pemampatan (subsiden), sehingga meskipun kandungan gambut per satuan volume meningkat, namun karena total volume gambut berkurang maka simpanan karbon secara total juga berkurang (Dariah et al., 2009).

\section{Satuan Lahan Homogen}

Satuan lahan homogen dibuat dengan menumpang tindihkan (overlay) data-data yang didapat pada survei utama yang telah disajikan dalam bentuk peta. Adapun petapeta yang dioverlay untuk mendapatkan satuan lahan homogen adalah peta ketebalan gambut, peta jenis tanah dan peta tingkat kematangan gambut lapisan permukaan (0-60 $\mathrm{cm}$ ). 
Tabel 4. Uraian faktor-faktor pembeda satuan lahan homogen

\begin{tabular}{|c|c|c|}
\hline \multicolumn{3}{|c|}{ Faktor Pembeda } \\
\hline I & II & III \\
\hline Ketebalan Gambut (cm) & Jenis Tanah & $\begin{array}{c}\text { Kematangan } \\
\text { Permukaaan }(0-60 \mathrm{Cm})\end{array}$ \\
\hline $1.300-400$ & 1. Haplofibrists & 1. Fibrik \\
\hline 2. $401-500$ & 2. Haplohemists & 2. Hemik \\
\hline $3.501-600$ & 3. Haplosaprists & 3. Saprik \\
\hline 4. $>600$ & $-\quad 1+2-1$ & - \\
\hline
\end{tabular}

Data ketebalan gambut, jenis tanah, dan tingkat kematangan gambut lapisan permukaan $(0-60 \mathrm{~cm})$ pada setiap titik bor diolah dan dikombinasikan untuk menentukan satuan lahan homogen. Berdasarkan kombinasi dari ketiga faktor pembeda satuan lahan homogen (SLH) yaiu ketebalan gambut (I), jenis tanah (II) dan kematangan gambut lapisan permukaaan $(0-60 \mathrm{~cm})$ (III), maka diproleh 12 satuan lahan homogen.

Tabel 5. Satuan lahan homogen

\begin{tabular}{|c|c|c|c|c|}
\hline No. & Kode SLH & Keterangan & Luas (Ha) & Persentase \\
\hline 1 & 222 & $\begin{array}{l}\text { Ketebalan } 400-500 \mathrm{~cm}, \text { Jenis Tanah } \\
\text { Haplohemists dan Tingkat Kematangan } \\
\text { Gambut Permukaan Hemik }\end{array}$ & 600 & $31,58 \%$ \\
\hline 2 & 322 & $\begin{array}{l}\text { Ketebalan 500-600 cm, Jenis Tanah } \\
\text { Haplohemists dan Tingkat Kematangan } \\
\text { Gambut Permukaan Hemik }\end{array}$ & 100 & $5,26 \%$ \\
\hline 3 & 321 & $\begin{array}{l}\text { Ketebalan } 500-600 \quad \mathrm{~cm}, \text { Jenis } \text { Tanah } \\
\text { Hplohemists dan Tingkat } \\
\text { Gambut Permukaan Fibrik }\end{array}$ & 350 & $18,42 \%$ \\
\hline 4 & 422 & $\begin{array}{l}\text { Ketebalan >600 cm, Jenis Tanah } \\
\text { Haplohemists dan Tingkat Kematangan } \\
\text { Gambut Permukaan hemik }\end{array}$ & 250 & $13,15 \%$ \\
\hline 5 & 421 & $\begin{array}{l}\text { Ketebalan >600 cm, Jenis Tanah } \\
\text { Haplohemists dan Tingkat Kematangan } \\
\text { Gambut Permukaan Fibrik }\end{array}$ & 100 & $5,26 \%$ \\
\hline 6 & 312 & $\begin{array}{l}\text { Ketebalan } 500-600 \quad \mathrm{~cm}, \text { Jenis Tanah } \\
\text { Haplofibrists dan Tingkat } \\
\text { Gambut Permukaan Hemik }\end{array}$ & 100 & $5,26 \%$ \\
\hline 7 & 313 & $\begin{array}{l}\text { Ketebalan 500-600 cm, Jenis Tanah } \\
\text { Haplofibrists dan Tingkat Kematangan } \\
\text { Gambut Permukaan Saprik }\end{array}$ & 50 & $2,63 \%$ \\
\hline 8 & 211 & $\begin{array}{l}\text { Ketebalan } 400-500 \mathrm{~cm}, \text { Jenis Tanah } \\
\text { Haplofibrists dan Tingkat Kematangan } \\
\text { Gambut Permukaan Fibrik }\end{array}$ & 50 & $2,63 \%$ \\
\hline 9 & 332 & $\begin{array}{l}\text { Ketebalan 500-600 cm, Jenis Tanah } \\
\text { Haplosaprists dan Tingkat Kematangan } \\
\text { Gambut Permukaan Hemik }\end{array}$ & 50 & $2,63 \%$ \\
\hline 10 & 232 & $\begin{array}{l}\text { Ketebalan } 400-500 \mathrm{~cm}, \text { Jenis Tanah } \\
\text { Haplosaprists dan Tingkat Kematangan } \\
\text { Gambut Permukaan Hemik }\end{array}$ & 100 & $5,26 \%$ \\
\hline 11 & 123 & $\begin{array}{l}\text { Ketebalan } 300-400 \quad \mathrm{~cm}, \text { Jenis Tanah } \\
\text { Haplohemists dan Tingkat Kematangan } \\
\text { Gambut Permukaan Saprik }\end{array}$ & 100 & $5,26 \%$ \\
\hline 12 & 223 & $\begin{array}{l}\text { Ketebalan 400-500 cm, Jenis Tanah } \\
\text { Haplohemists dan Tingkat Kematangan } \\
\text { Gambut Permukaan Saprik }\end{array}$ & 50 & $2,63 \%$ \\
\hline Jumlah & & & 1.900 & $100 \%$ \\
\hline
\end{tabular}




\section{Berat Volume (Bulk Density)}

Nilai bulk density (BV) merupakan parameter yang menentukan kemampuan tanah untuk menahan suatu beban diatasnya. Nilai bulk density merupakan faktor penting dalam penentuan cadangan karbon pada lahan gambut. Nilai bulk density dipengaruhi oleh tingkat kematangan gambut, gambut saprik memiliki nilai bulk density lebih besar dibandingkan dengan gambut fibrik dan hemik.

Tabel 6. Nilai bulk density (BV) pewakil

\begin{tabular}{ccc}
\hline Tingkat Dekomposisi & $\begin{array}{c}\text { Tkt. Dekomposisi } \\
\text { Sampel Pewakil }\end{array}$ & $\begin{array}{c}\text { Rataan Bulk } \text { Density } \\
\left(\mathbf{g} / \mathbf{c m}^{\mathbf{3}}\right.\end{array}$ \\
\hline Fibrik & Fibrik & 0,105739 \\
Hemik & Hemik & 0,123247 \\
Saprik & Saprik & 0,130974 \\
\hline
\end{tabular}

Sumber : Analisis laboratorium sampel pewakil pada setiap tingkat kematangan (fibrik, hemik dan saprik)

Nilai bulk density gambut di lokasi penelitian seperti yang terlihat pada Tabel 6 diatas berkisar antara $0,1057-0,1309 \mathrm{~g} / \mathrm{cm}^{3}$. Nilai bulk density gambut dilokasi penelitian mendekati nilai bulk density tanah gambut pada umumnya yaitu berkisar antara 0,01 - 0,20 g/cm ${ }^{3}$ (Barchia, 2006). Tabel 6 menunjukkan tingkat kematangan gambut mempengaruhi nilai bulk density. Semakin rendah kematangan gambut, maka nilai bulk density akan semakin rendah. Nilai bulk density gambut juga dipengaruhi oleh kedalaman gambut, semakin dalam gambut maka nilai bulk density nya akan semakin rendah.

\section{C-organik}

C-organik merupakan faktor penting dalam penentuan cadangan karbon pada lahan gambut. Nilai C-organik dipengaruhi oleh tingkat kematangan gambut, gambut fibrik memiliki nilai C-organik lebih tinggi dibandingkan dengan gambut hemik dan saprik.

Tabel 7. Nilai C-organik pewakil

\begin{tabular}{cccc}
\hline $\begin{array}{c}\text { Tingkat } \\
\text { Dekomposisi }\end{array}$ & $\begin{array}{c}\text { Tkt. Dekomp. } \\
\text { Sampel Pewakil }\end{array}$ & $\begin{array}{c}\text { Rataan } \\
\text { C-organik (\%) }\end{array}$ & $\begin{array}{c}\text { Rataan Bahan } \\
\text { Organik (\%) }\end{array}$ \\
\hline Fibrik & H3 & 56,833303 & 97,980614 \\
Hemik & H4,H5 & 56,291075 & 97,045814 \\
Saprik & H8,H9 & 55,617470 & 95,884519 \\
\hline
\end{tabular}

Sumber : Analisis laboratorium sampel pewakil pada setiap tingkat kematangan (fibrik, hemik dan saprik) 
Tabel 7 menunjukkan nilai C-organik pada lokasi penelitian berkisar antara 55,61 - 56,83\%. Nilai C-organik tersebut tersebut adalah relatif sama dengan hasil penelitian Salampak (1999) dan Handayani et al (2001), sebesar 50-58 \% dan lebih tinggi dari Melling et al (2005) dan Agus et al (2011), yakni 44,7 - 53,6 \%.

\section{Cadangan Karbon Tanah Gambut}

Faktor utama yang mempengaruhi jumlah cadangan karbon gambut adalah ketebalan gambut, bulk density, dan C-organik.

Tabel 8. Cadangan karbon setiap satuan lahan homogen

\begin{tabular}{cccccccc}
\hline SLH & $\begin{array}{c}\text { Luas } \\
(\mathbf{H a})\end{array}$ & $\begin{array}{c}\text { Ketebalan } \\
\text { Gambut } \\
(\mathbf{m})\end{array}$ & $\begin{array}{c}\text { Volume } \\
\left(\mathbf{m}^{\mathbf{3}}\right)\end{array}$ & $\begin{array}{c}\mathbf{B V} \\
\left(\mathbf{t o n} / \mathbf{m}^{\mathbf{3}}\right)\end{array}$ & $\begin{array}{c}\text { C-organik } \\
(\boldsymbol{\%})\end{array}$ & $\begin{array}{c}\text { Cadangan } \\
\text { Karbon/Ha } \\
(\mathbf{t o n})\end{array}$ & $\begin{array}{c}\text { Total } \\
\text { Karbon } \\
(\mathbf{t o n})\end{array}$ \\
\hline 1 & 600 & 4,73 & 28.380 .000 & 0,1187 & 56,4250 & $3.167,98$ & $1.900 .792,36$ \\
2 & 100 & 5,75 & 5.750 .000 & 0,1231 & 56,2844 & $3.997,80$ & $399.780,91$ \\
3 & 350 & 5,38 & 18.830 .000 & 0,1178 & 56,5594 & $3.584,53$ & $1.254 .585,91$ \\
4 & 250 & 6,52 & 16.300 .000 & 0,1172 & 56,4705 & $4.315,15$ & $1.078 .789,84$ \\
5 & 100 & 6,90 & 6.900 .000 & 0,1218 & 56,3331 & $4.734,37$ & $473.437,94$ \\
6 & 100 & 5,40 & 5.400 .000 & 0,1070 & 56,7931 & $3.281,50$ & $328.150,70$ \\
7 & 50 & 5,00 & 2.500 .000 & 0,1217 & 56,3041 & $3.426,10$ & $171.305,22$ \\
8 & 50 & 4,20 & 2.100 .000 & 0,1069 & 56,7830 & $2.549,44$ & $127.472,16$ \\
9 & 50 & 6,00 & 3.000 .000 & 0,1233 & 56,2404 & $4.160,66$ & $208.033,24$ \\
10 & 100 & 4,88 & 4.880 .000 & 0,1241 & 56,2150 & $3.400,93$ & $340.093,72$ \\
11 & 100 & 3,55 & 3.550 .000 & 0,1120 & 56,5958 & $2.250,24$ & $225.024,90$ \\
12 & 50 & 4,20 & 2.100 .000 & 0,1243 & 56,1948 & $2.933,70$ & $146.685,29$ \\
\hline \multicolumn{7}{c}{ Jumlah } \\
\hline
\end{tabular}

Tabel 8 menunjukkan jumlah total cadangan karbon di areal penelitian seluas 1900 ha yaitu 6.654.152,19 ton dengan jumlah cadangan karbon perhektar berkisar antara 2.250,24 ton $-4.734,37$ ton. Menurut Page et al (2010), jumlah cadangan karbon pada tanah gambut dipengaruhi oleh karakteristik gambut antara lain ketebalan gambut, kematangan gambut, dan bulk density (BV). Menurut Agus dan Subiksa (2008), cadangan karbon dalam setiap meter ketebalan gambut berkisar antara 300-700 ton/ha dan menurut Page et al (2002), rata-rata cadangan karbon pada tanah gambut setiap meter ketebalan gambut yaitu 600 ton/ha.

Tingkat kematangan gambut mempengaruhi nilai C-organik dan bulk density (BV). Nilai C-organik berkaitan dengan banyaknya karbon yang terkandung pada tanah gambut, sedangkan nilai bulk density (BV) mempengaruhi volume $\mathrm{C}$ yang terdapat pada tanah gambut. Menurut Agus et al., (2010) rata-rata kerapatan karbon gambut dengan 
tingkat kematangan saprik lebih besar dibandingkan dengan rata-rata kerapatan karbon gambut dengan tingkat kematangan fibrik dan hemik. Karakteristik gambut selain ketebalan gambut yaitu bulk density (BV) menjadi faktor utama dalam pendugaan cadangan karbon di lahan gambut (Prayitno, 2013).

\section{Prediksi Emisi Karbon}

Jumlah cadangan karbon total di lahan penelitian seluas $1900 \mathrm{Ha}\left(19000000 \mathrm{~m}^{2}\right)$ dengan tebal gambut rata-rata 5,38 $\mathrm{m}$ adalah 6654152,19 ton, maka jumlah cadangan

karbon dalam setiap $\mathrm{m}^{3}$ adalah $65,09 \mathrm{~kg} / \mathrm{m}^{3}$. Apabila kebakaran lahan menghilangkan lapisan gambut setebal $10 \mathrm{~cm}$ maka jumlah karbon yang hilang dan teremisi pada setiap $10 \mathrm{~cm}$ lapisan gambut adalah sebesar $6,509 \mathrm{~kg} / \mathrm{m}^{3}$, sehingga jumlah total karbon yang teremisi pada lahan penelitian seluas $1900 \mathrm{Ha}$ akibat hilangnya gambut setiap $10 \mathrm{~cm}$ karena terbakar adalah sebesar 12367,1 ton $\mathrm{C}$ atau 6,509 ton/Ha.

\section{Upaya Pengelolaan Karbon Pada Lahan Gambut}

Upaya-upaya yang perlu dilakukan untuk menekan laju emisi karbon dan mempertahankan fungsi lahan gambut sebagai pengikat karbon dalam jumlah yang besar adalah dengan melakukan restorasi hidrologi dan revegetasi. Restorasi hidrologi meliputi kegiatan pembasahan gambut (rewetting) dan pembuatan sekat kanal (kanal blocking). Revegetasi adalah kegiatan penanaman kembali spesies asli tanaman hutan gambut.

Pembasahan kembali (rewetting) di kawasan gambut tropika yang terdegradasi akan memberikan keuntungan dalam rehabilitasi. Secara langsung, gambut yang basah menghambat terjadinya kebakaran dan selanjutnya akan membantu pertumbahan vegetasi. Gambut yang telah dibasahi akan mencegah lepasnya emisi karbon (Suryadiputra, 2015).

Upaya lain yang harus dilakukan untuk menekan jumlah emisi karbon selain melakukan restorasi hidrologi adalah dengan melakukan revegetasi spesies tanaman asli. Revegetasi hendaknya dilakukan setelah tata air di lahan gambut dibenahi. Adanya vegetasi di permukaan gambut akan meningkatkan penyerapan (sekuestrasi) gas rumah kaca (GRK) akibat adanya aktivitas fotosintesa oleh tanaman. Ketika lahan gambut masih ditutupi vegetasi hutan alami dan tidak didrainase, maka vegetasi pada kawasan tersebut akan menyerap $\mathrm{CO}_{2}$ dari atmosfer dan menyimpannya sebagai biomasa tanaman, dan sebagai materi gambut pada lantai hutan. 


\section{Kaji Banding Deposit Karbon}

Simpanan karbon di lahan gambut bergantung kepada tipe deposit gambutnya. Wösten and Ritzema (2002) dalam Hooijer (2006), mengasumsikan cadangan karbon gambut di Asia Tenggara adalah sebesar $60 \mathrm{~kg} / \mathrm{m}^{3}$. Asumsi nilai cadangan karbon tersebut tidak menyertakan data mengenai nilai bulk density (BV) dan nilai C-organik tanah yang dipakai untuk menghitung cadangan karbon gambut sehingga menimbulkan ketidakpastian dalam perolehan cadangan karbonnya.

Jumlah cadangan karbon total di lahan penelitian seluas $1900 \mathrm{Ha}$ dengan tebal gambut rata-rata 5,38 $\mathrm{m}$ dan volume gambut total $102.220 .000 \mathrm{~m}^{3}$ adalah 6.654.152,19 ton, maka jumlah cadangan karbon dalam setiap $\mathrm{m}^{3}$ adalah $65,09 \mathrm{~kg} / \mathrm{m}^{3}$. Jumlah ini lebih tinggi dibanding asumsi umum jumlah cadangan karbon gambut di Asia Tenggara yang dikemukakan oleh Wösten and Ritzema (2002) dalam Hooijer (2006), yang hanya $60 \mathrm{~kg} \mathrm{C} / \mathrm{m}^{3}$. Jika jumlah cadangan karbon di lokasi penelitian dihitung berdasarkan asumsi umum cadangan karbon gambut Asia Tenggara sebesar $60 \mathrm{~kg} \mathrm{C} / \mathrm{m}^{3}$ maka jumlah cadangan karbon di lokasi penelitian seluas 1900 Ha hanya sebesar 6.133.200 ton. Hasil perhitungan menunjukkan adanya selisih jumlah cadangan karbon sebesar $520.299,8$ ton C pada lokasi penelitian seluas $1900 \mathrm{Ha}$.

\section{KESIMPULAN}

1. Areal studi penelitian seluas 1900 Ha memiliki total jumlah cadangan karbon sebesar 6.655.285,75 ton atau sebesar 3.502 ton karbon/Ha.

2. Cadangan karbon dalam jumlah yang sangat besar pada lahan gambut akan menjadi suatu permasalahan terkait isu lingkungan dan pemanasan global apabila teremisi ke atmosfer sebagai gas rumah kaca (GRK).

3. Jumlah total karbon yang teremisi pada lahan penelitian seluas 1900 Ha akibat hilangnya gambut setiap $10 \mathrm{~cm}$ karena terbakar adalah sebesar 12367,1 ton $\mathrm{C}$ atau sebesar 6,509 ton/Ha.

\section{DAFTAR PUSTAKA}

Agus F. 2009. Cadangan karbon emisi gas rumah kaca dan konservasi lahan gambut. Prosiding Seminar Dies Natalis Universitas Brawidjaya ke 46. 31 Januari 2009. Malang.

Agus F. IGM Subiksa. 2008. Lahan Gambut: Potensi untuk pertanian dan aspek lingkungan. Balai Penelitian Tanah dan World Agroforestry Centre. Bogor. 
Agus F. K Hairiah dan A Mulyani. 2011. Pengukuran Cadangan Karbon Tanah Gambut. Petunjuk Praktis. World Agroforestry Centre-ICRAF. SEA Regional Office dan Balai Besar Penelitian dan Pengembangan Sumberdaya Lahan Pertanian (BBSDLP). Bogor. Indonesia.

Andriesse JP. 2003. Ekologi dan Pengelolaaan Tanah Gambut Tropika. Cahyo Wibowo dan Istomo [penerjemah]. Bogor. Fakultas Kehutanan. Institut Pertanian Bogor.

Dariah A. E Susanti. E Surmaini dan F Agus. 2009. Karbon tersimpan di lahan gambut dengan berbagai penggunaan di Kabupaten Kubu Raya dan Pontianak Kalimantan Barat. Disampaikan pada Seminar Nasional Sumberdaya Lahan Pertanian. Balai Besar Litbang Sumberdaya Lahan Pertanian. Badan Litbang Pertanian.

Ginoga K. M Lugina. D Djaenudin. 2005. Kajian Kebijakan Pengelolaan Hutan Lindung (Policy Analysis Of Protection Forest Management). Jurnal Penelitian Sosial \& Ekonomi Vol. 2 No. 2 Juli Tahun 2005.

Handayani IP. P Prawito dan P Lestari. 2001. Fraksional Pool Bahan Organik Labil pada Hutan dan Lahan Pasca Deforestasi. Jurnal Ilmu Ilmu Pertanian Indonesia. 2 (2): $75-83$.

Hooijer. A Silvius. M Wösten. H Page. 2006. PEAT-CO2 Assessment of CO2 emissions from drained peatlands in SE Asia. Delft Hydraulics report Q3943 . 2006.

Melling. L Hatano and KJ Goh. 2005. Soil $\mathrm{CO}_{2}$ Flux From Ecosystem in Tropical Peat Land of Serawak. Malaysia. Tell us. 57: 1-11.

Page SE. F Siegert. JO Rieley. HDV Boehm. A Jaya. SH Limin. 2002. The amount of carbon released from peat and forest fires in Indonesia during 1997. Nature. 420. 61-65.

Saharjo BH. 2000. Fire research and society interent as limiting factors in minimizing large forest fires in Indonesia.

Salampak. 1999. Peningkatan Produktivitas Tanah Gambut yang Disawahkan dengan Pemberian Bahan Amelioran Tanah Mineral Berkadar Besi Tinggi. Disertasi. Sekolah Pascasarjana Institut Pertanian Bogor. Bogor.

Suswati D. B Hendro. D Shiddieq dan D Indradewa. 2011. Identifikasi Sifat Fisik Lahan Gambut Rasau Jaya III Kabupaten Kubu Raya Untuk Pengembangan Jagung. Jurnal Perkebunan dan Lahan Tropika. 1: 31-40.

Suwondo S. Sabiham. Sumardjo dan B Paramudya. 2011. Efek Pembukaan Lahan terhadap karakt eristik Biofisik Gambut pada Perkebunan Kelapa Sawit di Kabupaten Bengkalis. Jurnal Natur Indonesia. 14 (2): 143 - 149.

Wahyunto. H Subagjo. S Ritung and H Bekti. 2007. Map of Peatland Distribution Area and Carbon Content in Papua. Wetland International- Indonesia Program and Wildlife Habitat Canada (WHC). 
Wahyunto. S Ritung. Suparto. H Subagjo. 2005. Sebaran Gambut dan Kandungan Karbon di Sumatera dan Kalimantan. Proyek Climate Change, Forests and Peatlands in Indonesia. Wetlands International - Indonesia Programme dan Wildlife Habitat Canada. Bogor.

WWF. 2016. Term Of Reference Rehabilitasi Hutan Lindung Gambut (Hlg) Londerang Desa Rawasari, Kecamatan Berbak, Kabupaten Tanjung Jabung Timur Proyek Mca-I Rimba.

Zaini. 2011. Pendugaan Cadangan Karbon Biomassa Di Lahan Gambut Kebun Meranti Paham , Pt Perkebunan Nusantara Iv , Labuhan Batu, Sumatera Utara. Skripsi. Departemen Ilmu Tanah Dan Sumberdaya Lahan Fakultas Pertanian Institut Pertanian Bogor 2011. 